$\underline{\beta}=-m$

\title{
Bioavailability pharmacokinetics and residues of marbofloxacin in normal and $E$.coli infected broiler chicken
}

\author{
Ashraf El-Komy ${ }^{1 *}$, Taha Attia ${ }^{2}$, Amera Abd El Latif ${ }^{3}$, Hanem Fathy ${ }^{2}$ \\ ${ }^{1}$ Department of Pharmacology, Faculty of Veterinary Medicine, Benha University, Egypt \\ ${ }^{2}$ Department of Pharmacology, Faculty of Veterinary Medicine, University of El-Sadat City, Egypt \\ ${ }^{3}$ Department of Pharmacology, Faculty of Veterinary Medicine, Kafre El Sheikh University, Egypt \\ *Corresponding author E-mail: melhewaty@yahoo.com
}

\begin{abstract}
The pharmacokinetics of marbofloxacin was studied following a single intravenous, oral administration in normal broiler chickens and repeated oral administrations in normal and experimentally E.coli infected broiler chickens. The pharmacokinetic parameters following a single intravenous injection of $2 \mathrm{mg} / \mathrm{kg}$ b.wt., revealed that marbofloxacin obeyed a two compartments open model, distribution half-life $\left(\mathrm{t}_{0.5(\alpha)}\right)$ was $0.25 \pm 0.02 \mathrm{~h}$, volume of distribution $\left(\mathrm{V}_{\mathrm{dss}}\right)$ was $0.76 \pm 0.08 \mathrm{~L} / \mathrm{kg}$, elimination half-life $\left(\mathrm{t}_{0.5(\beta)}\right)$ was $5.43 \pm 0.87 \mathrm{~h}$ and total body clearance $\left(\mathrm{CL}_{\text {tot }}\right)$ was $0.09 \pm 0.002 \mathrm{l} / \mathrm{kg} / \mathrm{h}$. Following a single oral administration, marbofloxacin was rapidly and efficiently absorbed through gastrointestinal tract of chickens as the absorption half-life $\left(t_{0.5(a b)}: 0.62 \pm 0.02 \mathrm{~h}\right)$. Maximum serum concentration $\left(\mathrm{C}_{\max }\right)$ was $1.15 \pm 0.01 \mu \mathrm{g} / \mathrm{ml}$, reached its maximum time $\left(\mathrm{t}_{\max }\right)$ at $2.53 \pm 0.04 \mathrm{~h}$, elimination half-life $\left(\mathrm{t}_{0.5}(\mathrm{el})\right.$ ) was $7.36 \pm 0.20 \mathrm{~h}$ indicating the tendency of chickens to eliminate marbofloxacin in slow rate. Oral bioavailability was $73.57 \pm 1.90 \%$ indicating good absorption of marbofloxacin after oral administration. Serum concentrations of marbofloxacin following repeated oral administration of $2 \mathrm{mg} / \mathrm{kg}$ b.wt. once daily for five consecutive days, peaked 2 hours after each oral dose with lower significant values recorded in experimentally infected broiler chickens than in normal ones. Tissues residues of marbofloxacin in slaughtered normal chickens was highly in those tissues lung, liver, and kidneys in chickens and the chicken must not be slaughtered before 3 days of stopping of drug administration. It was concluded that the in- vitro protein binding was $12.33 \pm 0.82 \%$.
\end{abstract}

Keywords: Bioavailability, Broiler Chicken, Kinetic, Marbofloxacin.

\section{Introduction}

Fluoroquinolones are picking up ubiquity as imperative antibacterial agents in veterinary practice because of their broad antimicrobial activity (Park et al., 1998). Quinolones are dynamic against gram negative and gram positive microscopic organisms in vitro (Wolfson and Hooper, 1985), and in addition trimethoprim/sulfonamide resistant microbes (Preheim et al., 1987). What's more, these antimicrobials are likewise dynamic against Mycoplasma (Brown, 1996). Marbofloxacin is a synthetic fluoroquinolone, created for veterinary utilize just (Schneider et al., 1996). It acts by hindrance of bacterial DNA-gyrase and has high antimicrobial movement in vitro against an extensive variety of gram-negative and some gram-positive microscopic organisms (Staphylococcus aureus, Staphylococcus intermedius, Escherichia coli, Klebsiella sp., Pasteurella multocida, Pasteurella haemolytica, and Haemophilus somnus) and Mycoplasma (Spreng et al., 1995). Similar to other fluoroquinolones, marbofloxacin has low plasma protein binding (Ismail and El-Kattan, 2007), large volume of distribution with good concentrations in tissues and body fluids (Aliabadi and Lees, 2002; Anadon et al., 2002) and activity at extremely low concentrations (Ding et al., 2013).

The disposition kinetic of marbofloxacin has been evaluated in some avian species like broiler chickens (Anadon et al., 2002; Ding et al., 2013), ostriches (De Lucas et al., 2005), turkey (Haritova et al., 2006), Muscovy ducks (Goudah and Hasabelnaby, 2010; Yuan et al., 2011) and Mallard ducks (Garcia- Montijano et al., 2012). The point of this study is to examine the pharmacokinetic profile of marbofloxacin $(2 \mathrm{mg} / \mathrm{kg}$ b.wt.) taking after single intravenous, oral administration in normal chicken and repeated oral administrations in normal and experimentally E.coli infected broiler chicken. Also, tissue residues following repeated oral administrations in normal broiler chicken was evaluated.

\section{Materials and methods}

\subsection{Drug}

Marbofloxacin was obtained as injectable watery solution $2 \%$ under trade name (Marbocyl) ${ }^{\circledR}$ from Falcon`s Care Center, K.S.A. It manufactured by Vétoquinol S.A. (France). Each vial of $100 \mathrm{ml}$ capacity containing $20 \mathrm{mg}$ marbofloxacin/ $\mathrm{ml}$.

\subsection{Birds}

Thirty apparently healthy Cobb broiler chickens of both sexes weighing from 1000-1200 g. Chickens were obtained from a private poultry farm. The chickens were housed in hygienic floor system chambers and were fed on balanced antimicrobial free ration. Water was offered ad-libitum. Chickens were kept under observation for 2 weeks before the start of experiments to ensure complete clearance of any anti-bacterial substances from their bodies. The experiment was performed in accordance with the 
guidelines set by the Ethical Committee of El-Sadat city University, Egypt.

\subsubsection{Experimental design}

The chickens were divided into 3 groups:

Group 1

It included 6 normal chickens. Each bird was injected intravenously into the left wing vein with $2 \mathrm{mg}$ marbofloxacin / kg.b.wt. These chickens were left for 15 days after the intravenous injection to ensure complete excretion of marbofloxacin from their bodies. Then each chicken were given orally with $2 \mathrm{mg}$ marbofloxacin / kg.b.wt to calculate bioavailability of marbofloxacin in normal chickens.

Group 2

It included 6 normal chickens. Each bird was given orally with 2 $\mathrm{mg}$ marbofloxacin $/ \mathrm{kg}$.b.wt, once daily for five consecutive days, to determine the blood concentrations and pharmacokinetics of the drug.

Group 3

Six broiler chickens were used in this experiment. Each chicken was experimentally infected with a pathogenic strain of Escherichia coli.

(E. coli $\mathrm{O} 111: \mathrm{H} 4$ ) by injection of $0.5 \mathrm{ml}$ of the required concentration $\left(10^{7}\right.$ micro-organism $\left./ \mathrm{ml}\right)$ subcutaneously in the neck region of birds (Salehi et al., 2012). After appearance of the clinical symptoms of bacteraemia as fever and bloody diarrhea 48 hours post infection with Escherichia coli suspension, each infected bird was given marbofloxacin orally at dose rate of $2 \mathrm{mg} / \mathrm{kg} \mathrm{b}$.wt of once daily for five consecutive days.

Group 4

It included 18 chickens. Each bird was given orally with $2 \mathrm{mg}$ marbofloxacin $/ \mathrm{kg} . b . w t$, once daily for five consecutive days, to determine the blood and tissue residues.

\subsubsection{Samples}

Blood samples:- One $\mathrm{ml}$ blood was collected from the right wing vein of each bird at 5,15 and 30 minutes and 1, 2, 4, 6, 8, 12 and 24 hours after single intravenous and single oral administration. Blood samples following repeated oral administrations in normal chicken and experimentally infected chicken for 5 consecutive days were taken daily at 15, 30 minutes, 1, 2, 4, 6, 8, 12, 24 hours. All blood samples were collected in sterilized centrifuged tubes and allowed to clot. Serum was separated by centrifugation at 3000 r.p.m for 10 minutes. Sera were kept

frozen until assayed.

Tissue samples:- Three chickens (from group 4) were randomly selected and slaughtered, 2 hours then at $1^{\text {st }}, 2^{\text {nd }}, 3^{\text {rd }}, 4^{\text {th }}, 5^{\text {th }}$ and $6^{\text {th }}$ day after the last dose of drug administration. Tissues samples (liver, kidney, lung, spleen, fat, thigh muscle)

\subsubsection{Drug bioassay}

Concentrations of marbofloxacin in serum and tissue samples were determined by the microbiological assay method described by (Tsai and Kondo, 2001) using Escherichia coli ATCC 25922 as test organism.

Standard curves were constructed using antibacterial free serum collected from chickens. Six wells, $8 \mathrm{~mm}$ in diameter were cut at equal distances in standard Petri-dishes containing $25 \mathrm{ml}$ seeded agar. The wells were filled with $100 \mu$ of either the test samples or marbofloxacin standards. The plates were kept at room temperature for $2 \mathrm{~h}$ before being incubated at $37^{\circ} \mathrm{C}$ for $18 \mathrm{~h}$. Zones of inhibition were measured using micrometers, and the marbofloxacin concentrations in the test samples were calculated from the standard curve.

Standard curves of marbofloxacin were prepared in antibacterialfree chicken serum by the appropriate serial dilution. The standard curve in chicken serum was linear over the range of 0.05 to 100 $\mu \mathrm{g} / \mathrm{ml}$ and the value of correlation coefficient (r) was 0.78 . The limit of quantification was $0.05 \mu \mathrm{g} / \mathrm{ml}$. Protein binding of mar- bofloxacin was estimated according to (Craig and Suh, 1991). This method was based on the diffusion of free antibiotic into the agar medium. To estimate the protein binding of marbofloxacin, the drug was dissolved in phosphate buffer ( $\mathrm{pH}$ 7.2) and antibiotic free chicken's serum at different concentrations. This estimation was based on the facts that free unbound part of marbofloxacin only capable to diffuse through agar. The differences in the diameters of the inhibition zones between the solutions of the drug in the buffer and plasma samples were then calculated according to the following equation:

Protein binding $\%=$

Zone of inhibition in buffer - Zone of inhibition in serum / Zone of inhibition in buffer $\mathrm{x} 100$

\subsection{Pharmacokinetic analysis}

Serum concentrations of marbofloxacin for each individual chicken after IV and PO administrations were subjected to a compartmental analysis using a nonlinear least-squares regression analysis with the help of a computerized curve-stripping program (R Strip; Micromath Scientific Software, Salt Lake City, UT, USA). For IV and PO data, the appropriate pharmacokinetic model was determined by visual examination of individual concentration-time curves and by application of Akaike's Information Criterion (AIC) (Yamaoka et al., 1978). Following IV injection, the serum concentration time relationship was best estimated as a two compartment open model system (Baggot, 1978) according to the following biexponential equation:

$\mathrm{Cp}^{\mathrm{o}}=\mathrm{Ae}^{-\alpha \mathrm{t}}+\mathrm{Be}^{-\beta \mathrm{t}}$

where $\mathrm{Cp}^{\circ}$ is the concentration of drug in the serum at time t; $\mathrm{A}$ is the intercept of the distribution phase with the concentration axis expressed as ug $\mathrm{ml}^{-1}$; $\mathrm{B}$ is the intercept of the elimination phase with the concentration axis expressed as ug $\mathrm{ml}^{-1} ; \alpha$ is the distribution rate constant expressed in units of reciprocal time $\left(\mathrm{h}^{-1}\right) ; \beta$ is the elimination rate constant expressed in units of reciprocal time $\left(\mathrm{h}^{-1}\right)$; and $\mathrm{e}$ is the base of natural logarithm. The pharmacokinetic parameters were reported as mean \pm SD. Data obtained throughout the study were analyzed using Students t-test (Snedecor and Cochran, 1976).

\section{Results}

No clinical indications of antagonistic impacts or narrow mindedness were seen to marbofloxacin after intravenous or oral administration. Mean serum concentrations of marbofloxacin following intravenous and oral administration outlined in figure (1). Following a single intravenous injection of $2 \mathrm{mg} / \mathrm{kg}$ b.wt of marbofloxacin in normal chicken, marbofloxacin could be recognized therapeutically for 24 hours. The serum concentration - time curve of marbofloxacin following intravenous injection showed that the medication complied with a two compartments open model. Following oral administration of marbofloxacin, the mean peak serum concentrations $\left(\mathrm{C}_{\max }\right)$ were $1.15 \pm 0.01 \mu \mathrm{g} / \mathrm{mL}$ accomplished at time $\left(\mathrm{T}_{\max }\right) 2.53 \pm 0.04 \mathrm{~h}$. Marbofloxacin could be distinguished in a therapeutic concentration for $24 \mathrm{~h}$ after oral administration. The pharmacokinetics parameters of marbofloxacin following a single intravenous and oral administration were recorded in table (1). Oral administration of $2 \mathrm{mg} / \mathrm{kg}$.b.wt every 24 hours for five doses in normal and E.coli infected chicken uncovered a lower significant serum marbofloxacin concentration at all-time sampling in E.coli infected chicken than in normal ones. The pharmacokinetic parameters of marbofloxacin after repeated oral administration in normal chicken were compared to those in E.coli appeared in table (2). 


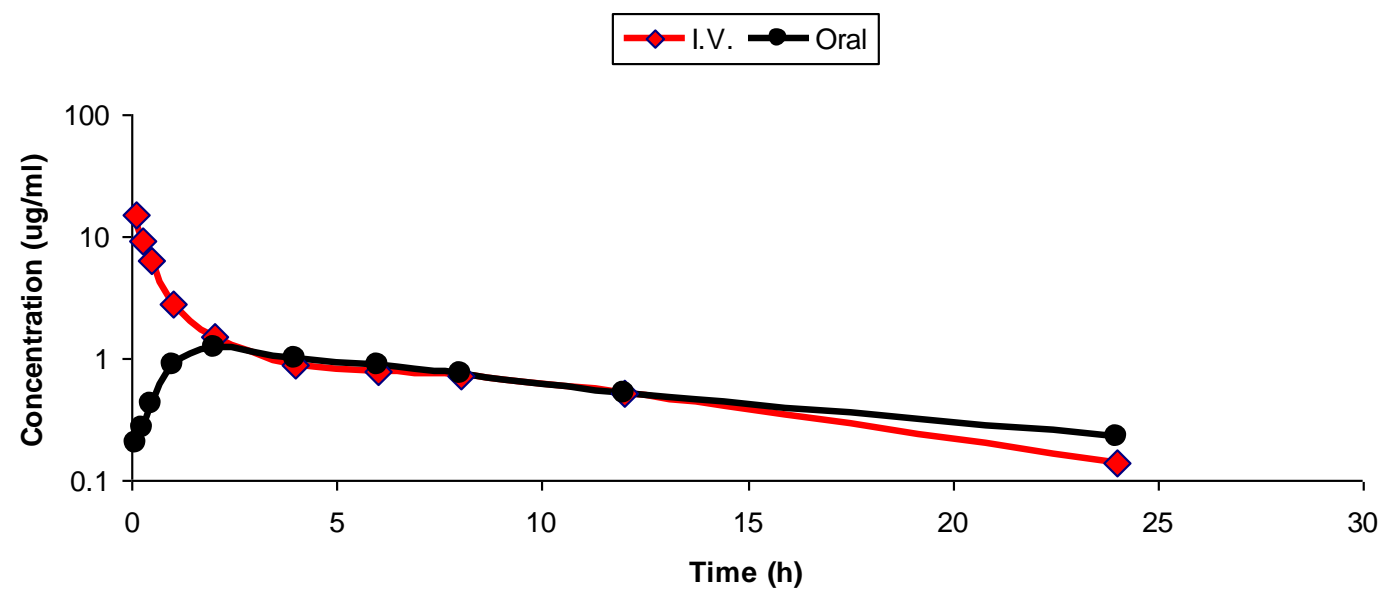

Fig. 1: Semilogarithmic Graph Depicting Serum Concentrations of Marbofloxacin $(\mu \mathrm{g} / \mathrm{Ml})$ Following a Single Oral Administration of $2 \mathrm{mg} / \mathrm{Kg}$ B.Wt. in Broiler Chickens Previously Given the Same Dose by A Single Intravenous Injection (N=6).

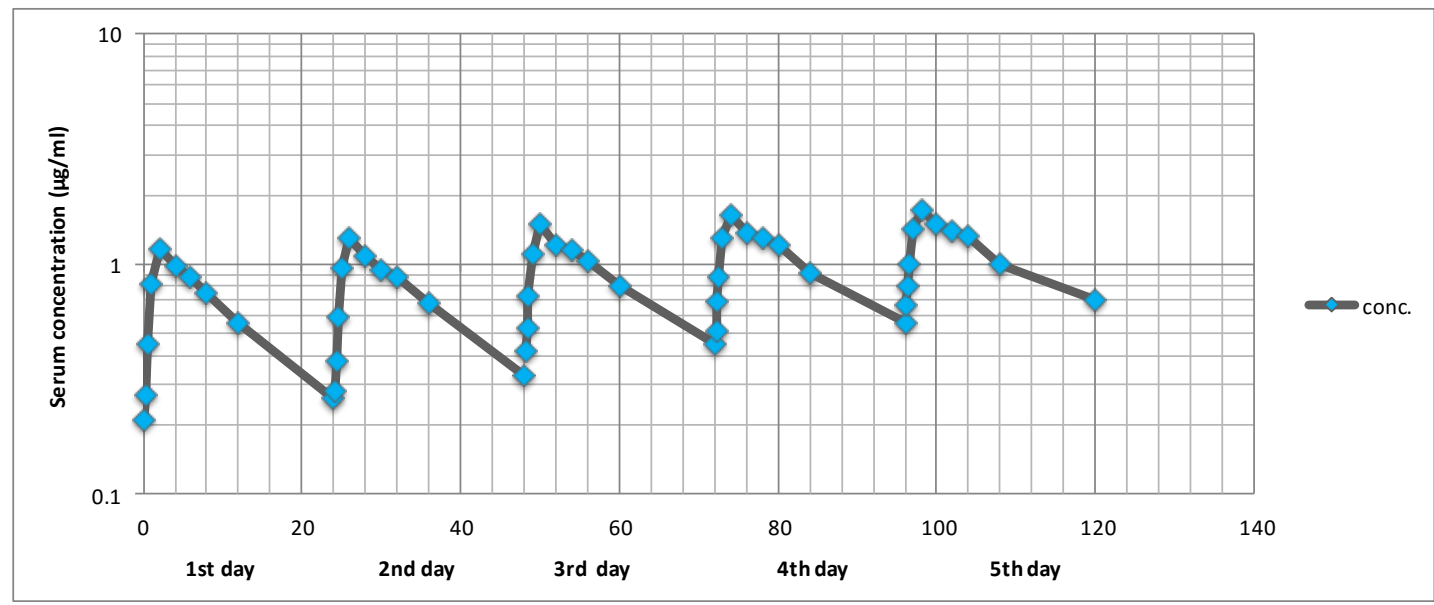

Fig. 2: Semilogarithmic Graph Depicting the Time Course of Marbofloxacin $(\mu \mathrm{g} / \mathrm{Ml})$ in Serum of Normal Broiler Chickens Following Repeated Oral Administration of $2 \mathrm{Mg} / \mathrm{Kg} \mathrm{B}$.Wt. Once Daily for Five Consecutive Days (N=6).

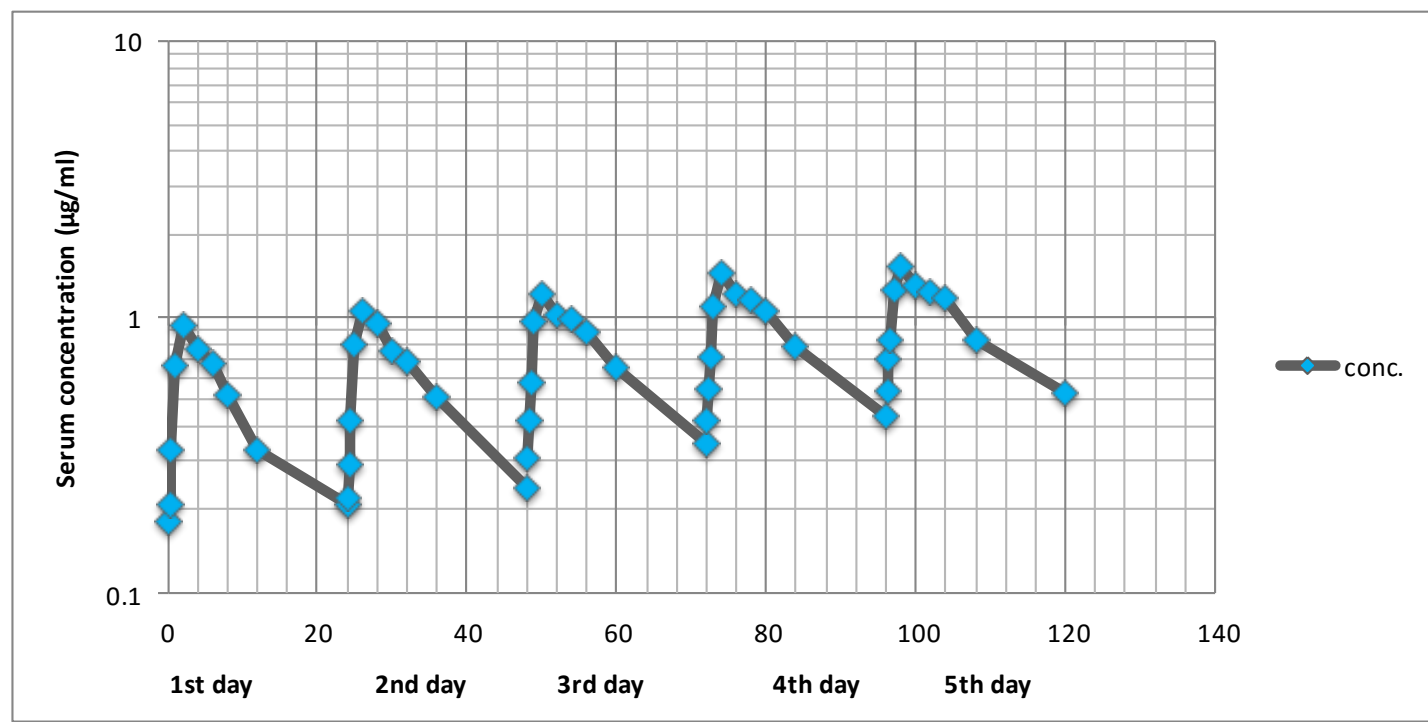

Fig. 3: Semilogarithmic Graph Depicting the Time Course of Marbofloxacin ( $\mu \mathrm{g} / \mathrm{Ml})$ in Serum of Infected Broiler Chickens Following Repeated Oral Administration of $2 \mathrm{Mg} / \mathrm{Kg}$ B.Wt. Once Daily for Five Consecutive Days (N=6). 
Table 1: Pharmacokinetic Parameters of Marbofloxacin in Chicken Following Single Intravenous and Oral Administration of $2 \mathrm{Mg} / \mathrm{Kg}$ B.Wt. (N=6)

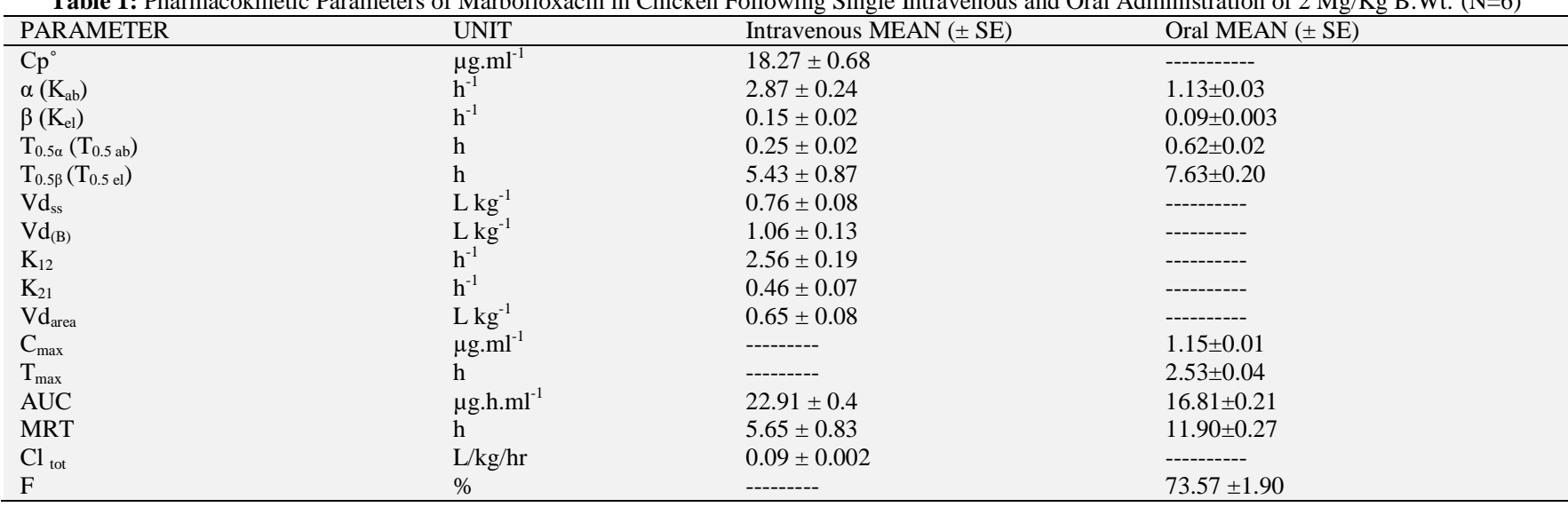

Table 2: Pharmacokinetic Parameters of Marbofloxacin ( $\mu \mathrm{g} / \mathrm{Ml})$ in Normal $(\mathrm{N})$ and Experimentally Escherichia Coli Infected (E) Broiler Chickens During Repeated Oral Administration of $2 \mathrm{Mg} / \mathrm{Kg}$.B.Wt. for Five Consecutive Days ( $\mathrm{N}=6)$.

\begin{tabular}{|c|c|c|c|c|c|c|c|c|c|c|}
\hline Days & $1^{\text {st }}$ day & & $2^{\text {nd }}$ day & & $3^{\text {rd }}$ day & & $4^{\text {th }}$ day & & $5^{\text {th }}$ day & \\
\hline $\begin{array}{l}\text { Parame- } \\
\text { ter } \\
\text { (unit) }\end{array}$ & $\begin{array}{l}\mathrm{N} \\
(\mathrm{X} \pm \text { S.E. })\end{array}$ & $\begin{array}{l}\mathrm{E} \\
(\mathrm{X} \pm \text { S.E. })\end{array}$ & $\begin{array}{l}\mathrm{N} \\
(\mathrm{X} \pm \text { S.E. })\end{array}$ & $\begin{array}{l}\mathrm{E} \\
(\mathrm{X} \pm \text { S.E. })\end{array}$ & $\begin{array}{l}\mathrm{N} \\
(\mathrm{X} \pm \text { S.E. })\end{array}$ & $\begin{array}{l}\mathrm{E} \\
(\mathrm{X} \pm \text { S.E. })\end{array}$ & $\begin{array}{l}\mathrm{N} \\
(\mathrm{X} \pm \text { S.E. })\end{array}$ & $\begin{array}{l}\text { E } \\
(X \pm \text { S.E. })\end{array}$ & $\begin{array}{l}\mathrm{N} \\
(\mathrm{X} \pm \text { S.E. })\end{array}$ & $\begin{array}{l}\mathrm{E} \\
(\mathrm{X} \pm \text { S.E. })\end{array}$ \\
\hline $\mathrm{K}_{\mathrm{ab}} \mathrm{h}^{-1}$ & $\begin{array}{l}1.15 \pm 0.0 \\
2\end{array}$ & $1.10 \pm 0.04$ & $\begin{array}{l}1.27 \pm 0.0 \\
3\end{array}$ & $1.18 \pm 0.03 *$ & $1.32 \pm 0.02$ & $1.32 \pm 0.03$ & $1.39 \pm 0.03$ & $1.26 \pm 0.04 *$ & $1.43 \pm 0.01$ & $1.36 \pm 0.02 *$ \\
\hline $\mathrm{T}_{0.5(\mathrm{ab})} \mathrm{h}$ & $\begin{array}{l}0.61 \pm 0.0 \\
1\end{array}$ & $0.64 \pm 0.02$ & $\begin{array}{l}0.55 \pm 0.0 \\
1\end{array}$ & $0.59 \pm 0.02$ & $\begin{array}{l}0.54 \pm 0.00 \\
8\end{array}$ & $0.53 \pm 0.01$ & $0.50 \pm 0.01$ & $0.55 \pm 0.02 *$ & $\begin{array}{l}0.49 \pm 0.00 \\
4\end{array}$ & $\begin{array}{l}0.51 \pm 0.005 \\
*\end{array}$ \\
\hline $\mathrm{K}_{\mathrm{el}} \mathrm{h}^{-1}$ & $\begin{array}{l}0.08 \pm 0.0 \\
03\end{array}$ & $\begin{array}{l}0.096 \pm 0.00 \\
5^{*}\end{array}$ & $\begin{array}{l}0.07 \pm 0.0 \\
02\end{array}$ & $\begin{array}{l}0.08 \pm 0.002 \\
* *\end{array}$ & $\begin{array}{l}0.06 \pm 0.00 \\
07\end{array}$ & $0.06 \pm 0.002$ & $\begin{array}{l}0.05 \pm 0.00 \\
08\end{array}$ & $\begin{array}{l}0.06 \pm 0.002 \\
* * *\end{array}$ & $\begin{array}{l}0.04 \pm 0.00 \\
2\end{array}$ & $0.05 \pm 3.10$ \\
\hline $\begin{array}{l}\mathrm{T}_{0.5(\mathrm{el})} \\
\mathrm{h}\end{array}$ & $\begin{array}{l}9.12 \pm 0.2 \\
6\end{array}$ & $\begin{array}{l}7.23 \pm 0.32 * \\
*\end{array}$ & $\begin{array}{l}10.50 \pm 0 . \\
27\end{array}$ & $\begin{array}{l}8.91 \pm 0.19 * \\
* *\end{array}$ & $\begin{array}{l}11.92 \pm 0.2 \\
24\end{array}$ & $11.43 \pm 0.35$ & $\begin{array}{l}13.34 \pm 0.1 \\
7\end{array}$ & $\begin{array}{l}11.85 \pm 0.36 \\
* *\end{array}$ & $\begin{array}{l}15.33 \pm 0.1 \\
29\end{array}$ & $\begin{array}{l}13.11 \pm 0.10 \\
* * *\end{array}$ \\
\hline $\begin{array}{l}C_{\max } \\
\mu \mathrm{g} / \mathrm{ml}\end{array}$ & $\begin{array}{l}1.08 \pm 0.0 \\
04\end{array}$ & $\begin{array}{l}0.86 \pm 0.008 \\
* * *\end{array}$ & $\begin{array}{l}1.20 \pm 0.0 \\
2\end{array}$ & $\begin{array}{l}1.00 \pm 0.005 \\
* * *\end{array}$ & $\begin{array}{l}1.37 \pm 0.00 \\
6\end{array}$ & $\begin{array}{l}1.16 \pm 0.004 \\
*\end{array}$ & $\begin{array}{l}1.53 \pm 0.00 \\
4\end{array}$ & $\begin{array}{l}1.36 \pm 0.01 * \\
* *\end{array}$ & $\begin{array}{l}1.62 \pm 0.00 \\
5\end{array}$ & $\begin{array}{l}1.43 \pm 0.02 * \\
* *\end{array}$ \\
\hline $\mathrm{T}_{\max } \mathrm{h}$ & $\begin{array}{l}2.61 \pm 0.0 \\
3\end{array}$ & $2.50 \pm 0.02 *$ & $\begin{array}{l}2.49 \pm 0.0 \\
5\end{array}$ & $2.51 \pm 0.03$ & $\begin{array}{l}2.48 \pm 0.01 \\
6\end{array}$ & $2.45 \pm 0.02$ & $2.40 \pm 0.03$ & $2.51 \pm 0.05$ & $2.38 \pm 0.02$ & $2.39 \pm 0.02$ \\
\hline $\begin{array}{l}\mathrm{AUC} \\
\mu \mathrm{g} / \mathrm{h} / \mathrm{ml}\end{array}$ & $\begin{array}{l}18.01 \pm 0 \\
43\end{array}$ & $\begin{array}{l}12.67 \pm 0.37 \\
* * *\end{array}$ & $\begin{array}{l}22.17 \pm 0 \\
40\end{array}$ & $\begin{array}{l}16.48 \pm 0.21 \\
* * *\end{array}$ & $\begin{array}{l}28.23 \pm 0.3 \\
7\end{array}$ & $\begin{array}{l}22.57 \pm 0.65 \\
* * *\end{array}$ & $\begin{array}{l}34.40 \pm 0.2 \\
9\end{array}$ & $\begin{array}{l}27.66 \pm 0.55 \\
* * *\end{array}$ & $\begin{array}{l}41.59 \pm 0.1 \\
9\end{array}$ & $\begin{array}{l}32.14 \pm 0.29 \\
* * *\end{array}$ \\
\hline MRT h & $\begin{array}{l}14.04 \pm 0 . \\
36\end{array}$ & $\begin{array}{l}11.34 \pm 0.44 \\
* * *\end{array}$ & $\begin{array}{l}15.94 \pm 0 . \\
39\end{array}$ & $\begin{array}{l}13.70 \pm 0.25 \\
* * *\end{array}$ & $\begin{array}{l}17.95 \pm 0.3 \\
1\end{array}$ & $17.25 \pm 0.49$ & $\begin{array}{l}19.91 \pm 0.2 \\
5\end{array}$ & $\begin{array}{l}17.85 \pm 0.51 \\
* *\end{array}$ & $\begin{array}{l}22.71 \pm 0.1 \\
8\end{array}$ & $\begin{array}{l}19.56 \pm 0.13 \\
* * *\end{array}$ \\
\hline IBD h & $\begin{array}{r}31.95 \\
\pm 1.18 \\
\end{array}$ & $\begin{array}{l}25.07 \\
\quad \pm 1.15 * * \\
\end{array}$ & $\begin{array}{r}37.99 \\
\pm 1.14 \\
\end{array}$ & $\begin{array}{l}31.23 \\
\quad \pm 0.69 * * * \\
\end{array}$ & $\begin{array}{r}43.56 \\
\pm 0.48 \\
\end{array}$ & $\begin{array}{r}40.46 \\
\pm 0.93 *\end{array}$ & $\begin{array}{l}53.73 \\
\pm 0.97\end{array}$ & $\begin{array}{l}45.90 \\
\quad \pm 1.68 * * \\
\end{array}$ & $\begin{array}{r}62.09 \\
\pm 2.75 \\
\end{array}$ & $\begin{array}{l}52.12 \\
\quad \pm 0.04 * * \\
\end{array}$ \\
\hline
\end{tabular}

\section{Discussion}

In the present examination, the intravenous injection of $2 \mathrm{mg} / \mathrm{kg}$ b.wt. of marbofloxacin in normal broiler chickens, demonstrated that the medication disposition best fitted a two compartments open model. The got result was predictable with those reported for marbofloxacin in mature horses (Carretero et al., 2002), goats (Waxman et al., 2004), cats (Albarellos et al., 2005), foals (Tohamy and El-Gendy, 2013) and quails (Aboubakr and Abdelazem, 2015).

Following a single intravenous injection of marbofloxacin in normal broiler chickens, the drug was quickly distributed with a distribution half-life $\left(\mathrm{T}_{0.5(\alpha)}\right)$ of $(0.25 \pm 0.02 \mathrm{~h})$. This outcome is almost reliable with those reported in broiler chickens $(0.12 \pm 0.02 \mathrm{~h}$; Anadon et al., 2002), Muscovy ducks $(0.34 \pm 0.12 \mathrm{~h}$; Goudah and Hasabelnaby, 2010b) and foals (0.27 h; Tohamy and El-Gendy, 2013). The highly distribution of fluoroquinolones attributable to their physicochemical properties (Mevius et al., 1990).

Additionally, marbofloxacin was wiped out at slow rate with elimination half-life $\left(\mathrm{T}_{0.5}(\beta)\right.$ of $5.43 \pm 0.87 \mathrm{~h}$. This outcome is about like that reported in broiler chickens $(5.26 \pm 0.66 \mathrm{~h}$; Anadon et al., 2002), goats (5.74 $\pm 1.21 \mathrm{~h}$; Dova et al., 2007) and chickens (6.8 h; Ding et al., 2013) and like those recorded for different fluoroquinolones in broiler chickens as pefloxacin, ofloxacin and danofloxacin $(3.25$ h, 4.44 h, 6.73 h, respectively; Varia et al., 2009) and norfloxacin in broiler chickens $(4.71 \pm 0.06 \mathrm{~h}$; El-Sayed et al., 2014). On the other hand, the elimination half-life in this study was shorter than those reported for ciprofloxacin in chickens $(8.84$ $\mathrm{h}$; Anadon et al., 2001) and marbofloxacin in calves (8.2 h; Ismail and El-Kattan, 2007) such contrasts are moderately regular and are often identified with inter species variation, assay methods used, the measure of time between blood examining, the health status and age of the animal (Haddad et al., 1985).

The Vdss for marbofloxacin was $0.76 \pm 0.08 \mathrm{~L} / \mathrm{kg}$. The obtained value was similar to that recorded for marbofloxacin $(0.77 \pm 0.25$ $\mathrm{L} / \mathrm{kg}$.) in broiler chickens (Anadon et al., 2002). Then again, these outcomes were contrast from those recorded for marbofloxacin $(3.22 \pm 0.98 \mathrm{~L} / \mathrm{kg})$ in ostriches (De-Lucas et al. 2005), (1.54 \pm 0.19 $\mathrm{L} / \mathrm{kg}$ ) in turkeys (Haritova et al. 2006) and $(1.78 \pm 0.37 \mathrm{~L} / \mathrm{kg}$ ) in Mallard ducks (Garcia-Montijano et al. 2012).

The rate of total body clearance $\left(\mathrm{Cl}_{\mathrm{tot}}\right)$ of marbofloxacin following intravenous injection was $0.09 \pm 0.002 \mathrm{~L} / \mathrm{kg} / \mathrm{h}$. This value was almost like those recorded in broiler chickens $(0.17 \pm 0.03 \mathrm{~L} / \mathrm{kg} / \mathrm{h})$ by Anadon et al. (2002) and pigs $(0.07 \mathrm{~L} / \mathrm{kg} / \mathrm{h})$ by Schneider et al. (2014).

Following oral administration, marbofloxacin was quickly absorbed through gastrointestinal tract of broiler chicken with short absorption half-life $\left(\mathrm{T}_{0.5(\mathrm{ab})}\right)$ of $0.62 \pm 0.02 \mathrm{~h}$. The got result is reliable with those reported for marbofloxacin in broiler chickens $(0.60 \pm 0.05 \mathrm{~h})$ Anadon et al. (2002), norfloxacin in broiler chickens $(0.57 \pm 0.01 \mathrm{~h})$ El-Sayed et al. (2014) and marbofloxacin in quails $(0.71 \pm 0.11 \mathrm{~h})$ Aboubakr and Abdelazem (2015). On the other hand, this value was longer than marbofloxacin in Muscovy ducks (0.27h) Goudah and Hasabelnaby (2010) and marbofloxacin in foals $(0.26 \pm 0.001 \mathrm{~h})$ Tohamy and El-Gendy (2013).

Maximum serum concentration (Cmax) was $1.15 \pm 0.01 \mu \mathrm{g} / \mathrm{ml}$ achived at (tmax) $2.53 \pm 0.04 \mathrm{~h}$. These values were similar to marbofloxacin $(1.05 \pm 0.15 \mu \mathrm{g} / \mathrm{ml})$ in broiler chickens (Anadon et al., 2002). Conversely, the reported maximum serum concentration in present study was lower than those recorded in quails $3.59 \pm 0.24$ $\mu \mathrm{g} / \mathrm{ml}$ (Aboubakr and Abdelazem, 2015) On the other hand, the 
acquired result of maximum serum concentration was higher than in turkey $0.80 \pm 0.32 \mu \mathrm{g} / \mathrm{ml}$ (Haritova et al., 2006).

The elimination half -life $\left(\mathrm{T}_{0.5 \mathrm{el}}\right)$ following single oral administration was $7.63 \pm 0.20 \mathrm{~h}$. The obtained result is similar to those reported for marbofloxacin in broiler chickens $(8.69 \pm 1.17 \mathrm{~h})$ Anadon et al., (2002), in turkey $(6.23 \pm 1.63$ h) Haritova et al., (2006) and in quails $(6.19 \pm 0.08 \mathrm{~h})$ Aboubakr and Abdelazem, (2015). This value was longer than marbofloxacin in Muscovy ducks $(2.63 \pm 0.44 \mathrm{~h})$ Goudah and Hasabelnaby, (2010). These distinctions are moderately basic and are as often as possible identified with between species variety, test techniques utilized, measure of time between blood inspecting and/or the wellbeing status and age of the creature (Haddad et al., 1985).

The systemic bioavailability of marbofloxacin in normal broiler chickens was $(73.57 \pm 1.90 \%)$. it was nearly similar to that of enrofloxacin $(68.11 \%)$ in Muscovy ducks (Intorre et al., 1997), ciprofloxacin $(69.12 \pm 6.95 \%)$ in broiler chickens (Anadon et al., 2001) and levofloxacin $(70.09 \pm 9.8 \%)$ in broiler chickens (Kalaiselvi et al., 2006). On the other hand, it was higher than values recorded for marbofloxacin $(56.82 \%)$ in broiler chickens (Anadon et al., 2002). This value of bioavailability was lower than that reported for ofloxacin $(110.01 \%)$ in chickens (Atta et al., 1997), difloxacin (86.20\%) in broiler chickens (Abo El-Ela et al., 2014) and marbofloxacin (87.94\%) in quails (Aboubakr and Abdelazem, 2015).

In this study, the in vitro protein binding of marbofloxacin to broiler chickens serum was $12.33 \pm 0.82 \%$. This demonstrates the medication is marginally bound to serum protein. This quality was about steady with those reported for danofloxacin (17.6\%) in Muscovy ducks (Goudah and Mouneir, 2009) and norfloxacin $(10.37 \%)$ in oven chickens (El-Sayed et al. 2014) yet it was lower than moxifloxacin (37.7\%) in grill chickens (Goudah, 2009) and marbofloxacin $(26.38 \%$ ) in quails (Aboubakr and Abdelazem, 2015). The results of in vitro protein binding may differ substantially depending on the technique and exploratory conditions (Zlotos et al., 1998).

The MIC of marbofloxacin has not yet been resolved for microscopic organisms separated from broiler chickens. To cover the greater part of the pathogens, in this discourse the $\mathrm{MIC}_{90}$ of 0.2 $\mu \mathrm{g} / \mathrm{ml}$ of marbofloxacin has been taken into consideration (Anadon et al., 2002 and Aboubakr and Abdelazem 2015). Based on this data, a dosage of $2 \mathrm{mg} / \mathrm{kg}$ marbofloxacin in broiler chickens would result in a $\mathrm{C}_{\max } / \mathrm{MIC}_{90}$ ratio of 5.75 which is similar to reported by Anadon et al. (2002) at ratio of 5.25.

The serum levels of marbofloxacin in Escherichia coli infected broiler chickens were significantly lower than those in normal broiler chickens following repeated oral administrations. These outcomes credited to the higher infiltrating force of marbofloxacin to the unhealthy tissues (Baggot, 1980). This phenomenon was similar to data recorded by Soliman (2000) who found that enrofloxacin concentrations in plasma of infected birds were lower than those of healthy ones. Likewise, El-Sayed et al. (2014) recorded that blood levels of norfloxacin in Escherichia coli infected broiler chicken were significally lower than those in normal chicken following repeated oral administrations. The higher serum concentrations of marbofloxacin after repeated doses compared to the first dose indicated the accumulation of marbofloxacin in blood. The results are agreed with the progressive daily increase in the mean serum concentrations following oral administration of norfloxacin in broiler chicken in a daily dose of $10 \mathrm{mg} / \mathrm{kg}$ for five consecutive days (El-Sayed et al. 2014).

The acquired result demonstrated that the drug was distributed in serum, and tested tissues (lung, liver, kidney, spleen, fat and thigh muscle). Lung and kidney had the most noteworthy grouping of marbofloxacin took after by liver and spleen, while the least fixation was resolved in fat and muscle. Comparable discoveries were previously reported for enrofloxacin in broiler chickens (AbdelAziz et al., 1997 and Soliman, 2000), marbofloxacin in broiler chickens (Anadon et al., 2002) and norfloxacin in broiler chickens (El-Sayed et al., 2014).
Utilizing the microbiological assay technique, marbofloxacin was still distinguished in serum and all tested tissues on the $2^{\text {nd }}$ day post last oral administration. The withdrawal period in this study is suspected to be three days. The obtained results were similar to those recorded after oral administration of marbofloxacin in broiler chickens at $2 \mathrm{mg} / \mathrm{kg}$ b.wt. for 3 days, withdrawal period of about 3 days (Anadon et al., 2002) and after oral administration of marbofloxacin in broiler chickens at $5 \mathrm{mg} / \mathrm{kg}$ b.wt. For 3 days, withdrawal period of about 4 days (Yang et al., 2014).

\section{Conclusion}

It could be concluded that oral administration of marbofloxacin at $2 \mathrm{mg} / \mathrm{kg}$ b.wt. may be highly efficacious against susceptible bacteria in broiler chicken. Chicken must not be slaughtered before 3 days of stopping marbofloxacin administration.

\section{Conflict of interests}

The authors declare that there is no conflict of interests regarding the publication of this article.

\section{References}

[1] Abarellos, G.A., Montoya, L. and Landoni, M.F. (2005) Pharmacokinetics of marbofloxacin after single intravenous and repeated oral administration to cats. Veterinary J,ournal, 170: 222-229. http://dx.doi.org/10.1016/j.tvj1.2004.05.011

[2] Abd El-Aziz, M.I., Aziza, M.A., Soliman, F.A. and Afify, N.A. (1997) Pharmacokinetic evaluation of enrofloxacin in chickens. British Poultry Science, 38: 164-168. http://dx.doi.org/10.1080/00071669708417963.

[3] Abo El-Ela, F.I., Radi, A.M., El-Banna, H., El-Gendy, A.A.M. and Tohamy, M.A. (2014) Pharmacokinetics of difloxacin in healthy and E-coli infected broiler chickens. British Poultry Science, 55: 830-836. http://dx.doi.org/10.1080/00071668.2014.960803.

[4] Aboubakr, M. and Abdelazem, A.M. (2015) Pharmacokinetics of marbofloxacin in Japanese quails (Coturnix japonica) after different routes of administration. Journal of American Science, 11: 136-142.

[5] Aliabadi, F.S. and Lees, P. (2002) Pharmacokinetics and pharmacokinetic/ pharmacodynamic integration of marbofloxacin in calf serum, exudate and transudate. Journal of Veterinary Pharmacology and Therapeutics, 25: 161-174 http://dx.doi.org/10.1046/j.1365-2885.2002.00399.x.

[6] Anadon, A., Martinez-Larranaga, M.R., Diaz, M.J., Martinez, M.A., Frejo, M.T., Martinez, M., Tafur, M. and Castellano, V.J. (2002) Pharmacokinetic characteristics and tissue residues for marbofloxacin and its metabolite N-desmethyl-marbofloxacin in broiler chickens. American Journal of Veterinary Research, 63: 927-933. http://dx.doi.org/10.2460/ajvr.2002.63.927.

[7] Anadon, A., Martinez-Larranaga, M. R., Iturbe, J., Martinez, M.A., Diaz, M.J., Frejo, M.T. and Martinez, M. (2001) Pharmacokinetics and residues of ciprofloxacin and its metabolites in broiler chickens. Research Veterinary Science Oct., 71: 101-119.

[8] Atta, A.H., Sharif, L. and Yaser,G. (1997) Pharmacokinetics of levofloxacin following intravenous and oral administration in broiler chickens. Journal of Veterinary Pharmacology and Therapeutics, 20: 326-329. http://dx.doi.org/10.1046/j.13652885.1997.00065.x.

[9] Baggot, J.D. (1978) some aspects of clinical pharmacokinetics in veterinary medicine. Journal of Veterinary Pharmacology and Therapeutics, 1: 5-18. http://dx.doi.org/10.1111/j.13652885.1978.tb00300.x.

[10] Baggot, J.D. (1980) Distribution of antimicrobial agents in normal and diseased animals. J.A.V.M.A., 19: 1085-1090.

[11] Brown, S.A. (1996) Fluoroquinolones in animal health. Journal of Veterinary Pharmacology and Therapeutics, 19: 1-14. http://dx.doi.org/10.1111/j.1365-2885.1996.tb00001.x.

[12] Carretèro, M., Rodriguez, C., San-Andrès, M.I., Forès, P., DeLucas, J.J., Nieto, J., Waxman, S., San-Andrès, M.D. and Gonzalez, F. (2002) Pharmacokinetics of marbofloxacin in mature horses after single intravenous and intramuscular administration. Equine Veterinary Journal, 34: 360-365 http://dx.doi.org/10.2746/042516402776249173. 
[13] Craig, A.W. and Suh, B. (1991) Protein binding and the antibacterial effects. Method for the determination of protein binding, in: LO RIAN, V. (Ed.) Antibiotics in Laboratory Medicine, $3^{\text {rd }}$ edn, (Baltimore, Maryland, USA, Williams \& Wilkins) pp. 367-402.

[14] De-Lucas, J.J., Rodriguez, C., Waxman, S., Gonzàlez, F., Uriarte, I. and San-Andrès, M.I. (2005) Pharmacokinetics of marbofloxacin after intravenous and intramuscular to Ostriches. Veterinary Journal, 170: 364-368. http://dx.doi.org/10.1016/j.tvj1.2004.06.012.

[15] Ding, H., Wang, L., Shen, X., Gu, X., Zeng, D. and Zeng, Z. (2013) Plasma and tissue pharmacokinetics of marbofloxacin in experimentally infected chickens with Mycoplasma gallisepticum and Escherichia coli. Journal of Veterinary Pharmacology and Therapeutics, 36: 511-515. http://dx.doi.org/10.1111/jvp.12049.

[16] Dova, S.W., San-Andres, M.D., Gonzalez, F., San-Andres, M.I. De-Lucas, J.J. and Rodriguez, C. (2007) Pharmacokinetic behavior and pharmacokinetic/pharmacodynamic integration of marbofloxacin after subcutaneous administration in goats. Veterinary Journal, 174: 425-427. http://dx.doi.org/10.1016/j.tvj1.2006.05.004.

[17] El-Sayed, M.G.A., El-Komy, A.A.A., Aboubakr, M.H. and El-Said A.M. (2014) Pharmacokinetics and tissue residues of norfloxacin in normal and experimentally $E$-coli infected broiler chickens. B.V.M.J., 26: 10-18.

[18] Garcia-Montijano, M., de Lucas, J.J., Rodríguez, C., González, F., San Andrés, M.I. and Waxman, S. (2012) Marbofloxacin disposition after intravenous administration of a single dose in wild mallard ducks. Journal of Avian Medicine and Surgery, 26: 6-10. http://dx.doi.org/10.1647/2011-007.1.

[19] Garica-Montijano, M., De-Lucas, J.J., Rodriguez, C., Gonzalez, F., De San-Andrès, M.I. and Waxman, S. (2012) Marbofloxacin disposition after intravenous administration of a single dose in wild mallard ducks (Anas Platyrhynchos). Journal of Avian Medicine and Surgery, 26: 6-10. http://dx.doi.org/10.1647/2011-007.1.

[20] Gouda, A. (2009) Pharmacokinetics and tissue residues of moxifloxacin in broiler chickens. British Poultry Science, 50: 251-258. http://dx.doi.org/10.1080/00071660802710108.

[21] Goudah, A. and Hasabelnaby, S. (2010) the disposition of marbofloxacin after single dose intravenous, intramuscular and oral administration to Muscovy ducks after. Journal of Veterinary Pharmacology and Therapeutics, 34: 197-201. http://dx.doi.org/10.1111/j.1365-2885.2010.01225.x.

[22] Goudah, A. and Mouneir, S.M. (2009) Disposition kinetics and tissue residues of danofloxacin in Muscovy ducks. British Poultry Science, 50 : 613-619. http://dx.doi.org/10.1080/00071660903147416

[23] Haddad, N.S., Pedersol, J.P., Ravis, W.R., Fazel, M.H. and Carson, R.L. (1985) Pharmacokinetics of gentamicin at steady-state in ponies, serum, urine and endometrial concentration. American Journal of Veterinary Research, 46: 1268-1271.

[24] Haritova, A.M., Rusenova, N.V., Parvanov, P.R., Lashev, L.D. and Fink-Gremmels, J. (2006) Integration of pharmacokinetic and pharmacodynamic indices of marbofloxacin in turkeys. Antimicrobial Agents Chemotherapy, 50: 3779-3785. http://dx.doi.org/10.1128/AAC.00711-05.

[25] Intorre L., Mengozzi, G., Bertini, S., Bagliacca, M., Luchetti, E. and Soldani, G. (1997) the plasma kinetics and tissue distribution of enrofloxacin and its metabolite ciprofloxacin in the Muscovy duck. Veterinary Research Communication, 21: 127-136. http://dx.doi.org/10.1023/A:1005773603905.

[26] Ismail, M. and El-Kattan, Y.A. (2007) Comparative pharmacokinetics of marbofloxacin in healthy and Mannheimia haemolytica infected calves. Research in Veterinary Science, 82: 398-404. http://dx.doi.org/10.1016/j.rvsc.2006.10.001

[27] Kalaiselvi, L., Sriranjani, D., Ramesh, S., Sriram, P. and Mathuram L.N. (2006) Pharmacokinetics of ofloxacin in broiler chicken. Journal of Veterinary Pharmacology and Therapeutics, 29:185 189. http://dx.doi.org/10.1111/j.1365-2885.2006.00729.x.

[28] Mevius, D.J., Breukink, H.J., Guelen, P.J.M., Jansen, T.D. and Greve, B.C. (1990: Pharmacokinetics, metabolism and renal clearance of flumequine in veal calves. Journal of Veterinary Pharmacology and Therapeutics, 13: 159-169. http://dx.doi.org/10.1111/j.1365-2885.1990.tb00764.x.

[29] Park, S.C., Yun, H.I. and Oh, T.K. (1998) Comparative pharmacokiretic profiles of two norfloxacin formulation after oral administration in rabbits. Journal of Veterinary Medicine and Science, 60 661-663. http://dx.doi.org/10.1292/jvms.60.661.

[30] Preheim, L., Cuevas, T., Roccaforte, J., Mellencamp, M. and Bittner, M. (1987) Oral use of ciprofloxacin in the treatment of elderly patients with complicated urinary tract infections due to tri- methoprim/ sulfamethoxazole-resistant bacteria. American Journal of Medicine, 82: 295-297.

[31] Salehi, T.Z., Tabatabaei, S., Karimi, V., Fasaei, B.N., Derakhshandeh, A. and Jahromi, A.O. 2012 Assessment of immunity against avain colibacillosis induced by an aroA mutant containing increased serum survival gene in broilers. Brazilian Journal Microbiology, 43: 363-370. http://dx.doi.org/10.1590/S151783822012000100043.

[32] Schneider, M., Paulin, A., Dron, F. and Woehrlè, F. (2014) Pharmacokinetics of marbofloxacin in pigs after intravenous and intramuscular administration of a single dose of $8 \mathrm{mg} / \mathrm{kg}$ : dose proportionality, influence of the age of animals and urinary elimination. Journal of Veterinary Pharmacology and Therapeutics, 37: 523-530. http://dx.doi.org/10.1111/jvp.12125.

[33] Schneider, M., Thomas, V., Boisrame, B. and Deleforge, J. (1996) Pharmacokinetics of marbofloxacin in dogs after oral and parenteral administration. Journal of Veterinary Pharmacology and Therapeutics, 19: 56-61. http://dx.doi.org/10.1111/j.13652885.1996.tb00009.x.

[34] Snedecor, G.W. and Cochran, T. (1976) "Statistical Methods" 6 th ed. pp. Ames, lowa U.S.A., 502-503.

[35] Soliman, G.A. (2000) Tissue distribution and disposition kinetics of enrofloxacin in healthy and E-coli infected broilers. Dtsch. Tierärztl. Wochenschr., 107: 23-27.

[36] Spreng, M., Deleforge, J., Thomas, V., Boisrame, B. and Drugeon, H. (1995) Antibacterial activity of marbofloxacin. A new fluoroquinolone for veterinary use against canine and feline isolates. Journal of Veterinary Pharmacology and Therapeutics, 18: 284 289. http://dx.doi.org/10.1111/j.1365-2885.1995.tb00592.x

[37] Tohamy, M.A. and El-Gendy, A.A.M. (2013) some pharmacokinetic aspects and bioavailability of marbofloxacin in foals. Beni-Suef University Journal of Basic and Applied Science, 2: 46-50. http://dx.doi.org/10.1016/j.bjbas.2013.09.007.

[38] Tsai, C.E. and Kondo, F. (2001) Improved agar diffusion method for detecting residual antimicrobial agents. Journal of Food Proectiont, 64: 361-366.

[39] Varia, D., Patel, H., Patel, U. D., Bhavsar, K. and Thaker, M. (2009) Disposition of levofloxacin following oral administration in broiler chickens. ISRAEL JOURNAL OF VETERINARY MEDICINE, 64:118-121.

[40] Waxman, S., San-Andrès, M.D., Gonzàlez, F., San-Andres, M.I., De-Lucas, J.J. and Rodriguez, C. (2004) Age-related changes in the pharmacokinetics of marbofloxacin after intravenous administration in goats. Journal of Veterinary Pharmacology and Therapeutics, 27: 31-35. http://dx.doi.org/10.1111/j.1365-2885.2004.00548.x.

[41] Wolfson, J.S. and Hooper, D.C. (1985) the fluroquinolones: structures, mechanism of action and resistance and spectra of activity in vitro. Antimicrobial Agents Chemotherapy, 28: 581-586. http://dx.doi.org/10.1128/AAC.28.4.581.

[42] Yang, F., Yang, Y.R., Wang, L., Huang, X.H., Qiao, G. and Zeng, Z.L. (2014) Estimating marbofloxacin withdrawal time in broiler chickens using a population physiologically based pharmacokinetics model. Journal of Veterinary Pharmacology and Therapeutics, 37: 579-588. http://dx.doi.org/10.1111/jvp.12137.

[43] Yamaoka, K., Nakagawa, T. and Uno, T. (1978) Statistical moment in pharmacokinetics. Journal of Pharmacokinetic and Biopharmaceutics, 6: 547-558. http://dx.doi.org/10.1007/BF01062109.

[44] Yuan, L.G., Wang, R., Sun, L.H., Zhu, L.X., Luo, X.Y., Sun, J., Fang, B.H. and Liu, Y.H. (2011) Pharmacokinetics of marbofloxacin in Muscovy ducks (Cairina moschata). Journal of Veterinary Pharmacology and Therapeutics, 34: 82- 85. http://dx.doi.org/10.1111/j.1365-2885.2010.01207.x.

[45] Zlotos, G., Bucker, A., Kinzing-Schippers, M., Sorgel, F. and Holzgrabe, U. (1998) Plasma protein binding of gyrase inhibitors. Journal of Pharmaceutical Scence, 87: 215-220. http://dx.doi.org/10.1021/js970181b. 